\title{
Job Satisfaction: A Comparative Analysis of Private and Public Sector Teachers of District West Bengal, India
}

\author{
Priyankar Singha ${ }^{1} *$, Dr. Souvik Raychaudhuri ${ }^{2}$
}

\section{ABSTRACT}

Teachers are building block of a nation. Teacher's role is very crucial in the growth of a country so that there is need to assess for improvement of their skills. The present study deals with job satisfaction among the teachers of private and public sector educational institute of west Bengal. Attempts were also made to assess their level of happiness and quality of inter personal relationship. The sample size was 100 divided into 2 groups i.e., private sector and public sector teacher. Each group was consisted respondents age ranging between 25-50 years and having minimum 2 years of job experience and each group was further divided into two sub groups i.e. male $(n=25)$ and female $(n=25)$. The data were collected from teaching employees of several private and public educational institutes (higher secondary schools, colleges, universities) of west Bengal. It reveals that public sector employees were found to be more satisfied than the private sector employees in their job and the similar result was also revealed for level of happiness and quality of interpersonal relationship. Furthermore, significant correlation has been found between job satisfaction and level of happiness and between job satisfaction and interpersonal relationship among the teachers of private and public sector institutes of west Bengal.

Keywords: Job Satisfaction, Private And Public Educational Institutes, Happiness And Interpersonal Relationship.

The role of teacher is very significant in the proper development of educational construct of a country. A teacher is a backbone of a nation and its progress depends upon the education system. He acts as a coach, mentor, trainer, and guide. But his performance totally depends on the interaction between working environment and subjective demands. Students learning ability and performance are the key judgment factors of a teacher's performance. Both Government and private institutes plays an important role in the growth of nation. Job satisfaction is one of the most important variable of a teacher which influence a student as well as whole community. It is

\footnotetext{
${ }^{1}$ Ph.D research scholar, Department of Psychology. Calcutta university

${ }^{2}$ Associate professor, Department of Psychology, Calcutta University

*Responding Author

(c) 2016 I P Singha, S Raychaudhri; licensee IJIP. This is an Open Access Research distributed under the terms of the Creative Commons Attribution License (http://creativecommons.org/licenses/by/2.0), which permits unrestricted use, distribution, and reproduction in any Medium, provided the original work is properly cited.
} 


\section{Job Satisfaction: A Comparative Analysis of Private and Public Sector Teachers of District West Bengal, India}

closely related to elements such as productivity, absenteeism, and turnover. The quality work has been done by active, dedicated and satisfied teachers. A dissatisfied teacher can never perform his duty adequately.

Job satisfaction or employee satisfaction has been defined in many different ways. Some believe it is simply how content an individual is with his or her job, in other words, whether or not they like the job or individual aspects or facets of jobs, such as nature of work or supervision (Spector, P.E. (1997). Hulin, C. L., \& Judge, T. A. (2003) believe it is not as simplistic as this definition suggests and instead that multidimensional psychological responses to one's job are involved. The concept of job satisfaction has been developed in many ways by many different researchers and practitioners. One of the most widely used definitions in organizational research is that of Locke (1976), who defines job satisfaction as "a pleasurable or positive emotional state resulting from the appraisal of one's job or job experiences" (p. 1304) (Locke, E. A. (1976). Others have defined it as simply how content an individual is with his or her job; whether he or she likes the job or not (Spector, P.E. (1997).

\section{LITERATURE REVIEW}

Work satisfaction has also been researched in the public-private context. DeSantis and Durst (1996) found that monetary reward and personal characteristics such as educational level are strongly related to job satisfaction in private employees while job significance and organizational climate is stronger for public employees. Buelens and Broeck (2007) draw attention to interesting aspects of job satisfaction. They conducted an empirical research with 3723 employees from both sectors in Belgium. The findings suggest that public employees have higher levels of work satisfaction because they experience less work-family conflict, they have fewer working hours, present less willingness to exert considerable effort on the behalf of the organization, and are less motivated by extrinsic rewards when compared to private sector employees.

Iqbal \& Akhtar (2012) compared the level of job satisfaction between male and female secondary school teachers in all public sector secondary school teachers working in district Lahore, Pakistan. Questionnaire was used for data collection and Job Satisfaction Scale for Teachers (JSST) was used for this purpose. One way ANOVA and t-test were applied to compare the satisfaction. Data analysis results showed that Female teachers were more satisfied with work and supervision aspects of job as compared with male teachers and also there is no significant difference in the job satisfaction between science \& arts and urban \& rural school teachers.

According to Maike et al (2010)"'Time is such a scarce source, flexible arrangements are a top indicator of work life equality and employee satisfaction.” According to Lisa (2008) "conflict between work and family was found to be a factor in many family problems such as depression 


\section{Job Satisfaction: A Comparative Analysis of Private and Public Sector Teachers of District West Bengal, India}

alcohol use and job satisfaction.” The balance between work and family affects every employee differently and the ability to manage these factors depends on the individual. Many teachers may be in this situation and these factors could influence their level of job satisfaction as measured in this survey.

\section{METHODOLOGY}

Hypothesis:

1. There is a significant difference between the private and public sector teachers regarding Job satisfaction, level of happiness and interpersonal relationship.

2. There is a significant difference between the male and female teachers regarding Job satisfaction, level of happiness and interpersonal relationship.

3. There will be a significant relationship between the variables (namely, job satisfaction, job satisfaction and level of happiness and interpersonal relationship) of private and public sector teachers.

\section{Research design:}

The present study is exploratory cum descriptive. The aim of this study is to compare the satisfaction level, level of happiness and the quality of interpersonal relationship between the teachers of private \& public educational institutes.

\section{Sample and data:}

Subjects of the present study were selected randomly from different private and public sector educational institutes (higher secondary schools, colleges and universities). A total no of 50 subjects were selected from each sector and thus the total sample size was $100(\mathrm{n}=100)$ diving into two groups i.e. private sector teacher $(\mathrm{n}=50)$ and public sector teacher $(\mathrm{n}=50)$. The subjects of each sector was further divided into 2 sub groups (male $=25$ and female $=25$ ).

\section{Data collection tools and measure:}

a) Job satisfaction was measured using job satisfaction scale by B.C. Muthayya (1973). The scale consisted of 34 items. The answer categories for each of the items were agree(A), not sure (NS), disagree(D) and not applicable(NA). The split-half reliability coefficient of the scale is 0.81 . The score range is $0-68$.

b) Level of happiness was measured using oxford happiness inventory (1980s). This inventory consisted of 29 items and each item having four incremental levels of response, numbered from 0 to 3 . The items receive the score same as the response given by the subjects, for e.g., response of 1 gets a score of 1 . The higher score denotes the higher level of happiness. The score ranges between $0-57$. The alpha reliability for the test is found to be 0.92 .

c) Inter-personal relationship was measured by applying interpersonal relationship inventory (Tilden, 1990). The scale consisted of 39 items and these items are divide into 3 domains such as social support, reciprocity and conflict. The test retest reliability for one 2 weeks is found to be 0.91 (social support), 0.84 (reciprocity) and 0.81(conflict). 
Job Satisfaction: A Comparative Analysis of Private and Public Sector Teachers of District West Bengal, India

Statistical tool:

Descriptive statistics and correlation statistics were done using spss (version 16.0).

\section{TABLES AND RESULT}

Table-1showing the difference in mean, standard deviation and ' $t$ ' values between private and public sector teachers. $(n=100$, private sector teachers $=50$, public sector teachers $=50)$.

\begin{tabular}{|l|l|l|l|l|l|l|}
\hline variables & \multicolumn{2}{l|}{$\begin{array}{l}\text { Private sector } \\
\text { teachers }\end{array}$} & \multicolumn{2}{|l|}{$\begin{array}{l}\text { Public sector } \\
\text { teachers }\end{array}$} & 't' values & $\begin{array}{l}\text { Level of } \\
\text { significance }\end{array}$ \\
\cline { 2 - 6 } & mean & $\begin{array}{l}\text { Standard } \\
\text { deviation }\end{array}$ & mean & $\begin{array}{l}\text { Standard } \\
\text { deviation }\end{array}$ & \\
\hline Job satisfaction & 40.68 & 8.68 & 49.38 & 4.78 & $6.209 * *$ & .000 \\
\hline happiness & 59.2 & 6.58 & 64.12 & 7.93 & $3.377^{* *}$ & .000 \\
\hline $\begin{array}{l}\text { Interpersonal } \\
\text { relationship }\end{array}$ & 156.06 & 6.55 & 162.04 & 4.91 & $5.165^{* *}$ & .000 \\
\hline
\end{tabular}

${ }^{* *} \mathrm{p}<0.01,{ }^{*} \mathrm{p}<0.05$

Table- 2, showing the difference in mean, standard deviation and ' $t$ ' values between the male and teachers. $(n=100$, male $=50$, female $=50)$.

\begin{tabular}{|l|l|l|l|l|l|l|}
\hline \multirow{2}{*}{ variables } & \multicolumn{2}{|l|}{ Male teachers } & \multicolumn{2}{l|}{ Female teachers } & 't' values & $\begin{array}{l}\text { Level of } \\
\text { significance }\end{array}$ \\
\cline { 2 - 6 } & mean & $\begin{array}{l}\text { Standard } \\
\text { deviation }\end{array}$ & mean & $\begin{array}{l}\text { Standard } \\
\text { deviation }\end{array}$ & & \\
\hline Job satisfaction & 42.90 & 8.50 & 47.16 & 7.43 & $2.27^{* *}$ & .00 \\
\hline happiness & 63.38 & 7.05 & 59.94 & 7.92 & $2.29 *$ & .02 \\
\hline $\begin{array}{l}\text { Sense of well } \\
\text { being }\end{array}$ & 161.52 & 6.02 & 156.58 & 6.04 & $4.09^{* *}$ & .00 \\
\hline
\end{tabular}

${ }^{* *} \mathrm{p}<0.01,{ }^{*} \mathrm{p}<0.05$

Table -3, Showing the product moment correlation coefficient values for the total group of male and female teachers for level of happiness and quality of interpersonal relationship with the level of job satisfaction $(n=100)$.

\begin{tabular}{|l|l|}
\hline variables & Correlation coefficient \\
\hline Job satisfaction - level of happiness & .138 \\
\hline Job satisfaction - interpersonal relationship & .162 \\
\hline
\end{tabular}

${ }^{* *} \mathrm{p}<0.01,{ }^{*} \mathrm{p}<0.05$

\section{DISCUSSION}

The study focuses on the job satisfaction between the teachers of private and public educational institute west Bengal, India and it's relationship to their level of happiness and quality of interpersonal relationship. The finding has been discussed in the light of the comparison between 


\section{Job Satisfaction: A Comparative Analysis of Private and Public Sector Teachers of District West Bengal, India}

the private and public sector teachers of west Bengal. Furthermore a comparison will be discussed as well on the basis of the gender difference.

Previous results explore that public sector teacher are found to be more satisfied to their job in comparison to private sector teachers. In case of level of happiness and quality of interpersonal relationship the similar result has been found which indicates that public sector teacher are more happier in their life and their interpersonal relationship are better in comparison to private sector employees.

The ' $t$ ' values has been found to be significant between private and public sector teachers for the variable job satisfaction, level of happiness and quality of interpersonal relationship. Thus, it may be sketch out that there is a significant difference between the teacher of private and public sector educational institute in west Bengal, India.

On the basis of table-2 it is observed that female teachers are more satisfied to their job than that of male teachers but in case of level of happiness and interpersonal relationship the male teachers are happy to their life than the female teacher and their interpersonal relationship is more effective than the female teacher. Furthermore, significant gender difference has been established for the present study.

Based on the correlation table it is clear that significant correlation could not be establish between job satisfaction and level of happiness and interpersonal relationship as well which indicated there is no association between job satisfaction and level of happiness and between job satisfaction and interpersonal relationship for the present sample of the study.

\section{LIMITATION OF THE STUDY:}

1. Respondent's opinions are dynamic; they keep changing from time to time.

2. Some of the respondents might not have given the actual information due to fear of being disclosed.

3. The results are confined to only few of army camps and cannot be generalized for other camps.

4. The study was conducted with the limited number of respondent due to time constraint.

5. Study may be obsolete because of changing environment and needs.

6. Satisfaction level to various factors may differ from person to person.

\section{CONCLUSION}

There does exist a significant difference between public sector teachers and private sector teachers of West Bengal in accordance to level of job satisfaction, level of happiness and interpersonal relationship and furthermore the public sector teacher are found to be more satisfied in their job than the private sector teachers in West Bengal. Gender difference was also 
found in the present study. Job satisfaction, level of happiness and sense of well being are not significantly correlated with each other among the teachers of West Bengal.

\section{REFERENCES}

Buelens, Marc; Van Den Roeck, Herman. An analysis of differences in work motivation between public and private organizations. Public Administration Review, v. 67, n. 1, p. 65-74, 2007.

DeSantis, V. S., and Durst, S. L. 1996. Comparing job satisfaction among public and private sector employees. American Review of Public Administration, 26(3), 327-343.

Hulin, C. L., \& Judge, T. A. (2003). Job attitUdes. In W. C. Borman, D. R. ligen, \& R. J. Klimoski (Eds.), Handbook of psychology: Industrial and organizational psychology (pp. 255-276). Hoboken, NJ: Wiley.

Iqbal, D. A., \& Akhtar, D. S. (2012). Job Satisfaction of Secondary School Teachers. Abasyn Journal of Social Sciences, 5 (1).

Lisa, A. (2008). Factors that affect job satisfaction among teachers in two selected Milwaukee charter schools. pp20.(master thesis, Capella University. School of Human Services).

Locke, E., The nature and causes of job satisfaction. In M. D. Dunnette (Ed.).Handbook of industrial and organizational psychology,Chicago:Rand McNally, 1297-1349, 1976

Maike, I. P., Timothy B. B.,(2010). Helping Faculty Find Work-Life Balance: The Path Toward FamilyFriendly.(1st ed.),pp14.

Spector, P.E. (1997). Job satisfaction: Application, assessment, causes and consequences. Thousand Oaks, CA: SAGE 